\title{
Diversity, distribution, and drivers of Polychromophilus infection in Malagasy bats
}

\author{
Mercia Rasoanoro 1,2, Steven M. Goodman ${ }^{3,4}$, Milijaona Randrianarivelojosia 1,5, Mbola Rakotondratsimba ${ }^{3}$,
} Koussay Dellagi ${ }^{6}$, Pablo Tortosa ${ }^{7}$ and Beza Ramasindrazana ${ }^{1,2^{*}}$

\begin{abstract}
Background: Numerous studies have been undertaken to advance knowledge of apicomplexan parasites infecting vertebrates, including humans. Of these parasites, the genus Plasmodium has been most extensively studied because of the socio-economic and public health impacts of malaria. In non-human vertebrates, studies on malaria or malarialike parasite groups have been conducted but information is far from complete. In Madagascar, recent studies on bat blood parasites indicate that three chiropteran families (Miniopteridae, Rhinonycteridae, and Vespertilionidae) are infected by the genus Polychromophilus with pronounced host specificity: Miniopterus spp. (Miniopteridae) harbour Polychromophilus melanipherus and Myotis goudoti (Vespertilionidae) is infected by Polychromophilus murinus. However, most of the individuals analysed in previous studies were sampled on the western and central portions of the island. The aims of this study are (1) to add new information on bat blood parasites in eastern Madagascar, and (2) to highlight biotic and abiotic variables driving prevalence across the island.
\end{abstract}

Methods: Fieldworks were undertaken from 2014 to 2016 in four sites in the eastern portion of Madagascar to capture bats and collect biological samples. Morphological and molecular techniques were used to identify the presence of haemosporidian parasites. Further, a MaxEnt modelling was undertaken using data from Polychromophilus melanipherus to identify variables influencing the presence of this parasite

Results: In total, 222 individual bats belonging to 17 species and seven families were analysed. Polychromophilus infections were identified in two families: Miniopteridae and Vespertilionidae. Molecular data showed that Polychromophilus spp. parasitizing Malagasy bats form a monophyletic group composed of three distinct clades displaying marked host specificity. In addition to P. melanipherus and P. murinus, hosted by Miniopterus spp. and Myotis goudoti, respectively, a novel Polychromophilus lineage was identified from a single individual of Scotophilus robustus. Based on the present study and the literature, different biotic and abiotic factors are shown to influence Polychromophilus infection in bats, which are correlated based on MaxEnt modelling.

Conclusions: The present study improves current knowledge on Polychromophilus blood parasites infecting Malagasy bats and confirms the existence of a novel Polychromophilus lineage in Scotophilus bats. Additional studies are needed to obtain additional material of this novel lineage to resolve its taxonomic relationship with known members of the genus. Further, the transmission mode of Polychromophilus in bats as well as its potential effect on bat populations should be investigated to complement the results provided by MaxEnt modelling and eventually provide a comprehensive picture of the biology of host-parasite interactions.

\footnotetext{
*Correspondence: rbeza@pasteur.mg

2 Faculté des Sciences, Université d'Antananarivo, BP 706, Antananarivo

101, Antananarivo, Madagascar

Full list of author information is available at the end of the article
}

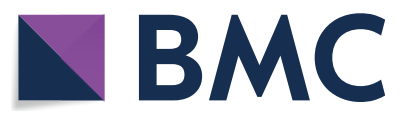

(c) The Author(s) 2021. This article is licensed under a Creative Commons Attribution 4.0 International License, which permits use, sharing, adaptation, distribution and reproduction in any medium or format, as long as you give appropriate credit to the original author(s) and the source, provide a link to the Creative Commons licence, and indicate if changes were made. The images or other third party material in this article are included in the article's Creative Commons licence, unless indicated otherwise in a credit line to the material. If material is not included in the article's Creative Commons licence and your intended use is not permitted by statutory regulation or exceeds the permitted use, you will need to obtain permission directly from the copyright holder. To view a copy of this licence, visit http://creativeco mmons.org/licenses/by/4.0/. The Creative Commons Public Domain Dedication waiver (http://creativecommons.org/publicdomain/ zero/1.0/) applies to the data made available in this article, unless otherwise stated in a credit line to the data. 
Keywords: Bats, Polychromophilus, Eastern, MaxEnt, Madagascar

\section{Background}

In recent years, studies in different areas of the world have elucidated the biology, ecology, diversity, and evolutionary history of apicomplexan parasites infecting vertebrates [1-4]. Among these blood parasites, the genus Plasmodium has been the most intensively studied because of the millions of cases of malaria recorded per year, leading to more than 400,000 deaths annually in humans [5]. Plasmodium also infects different groups of vertebrates, such as reptiles, birds, and mammals, including bats [6-8]. The genus Plasmodium is now recognized to be polyphyletic and species diversification has led to the evolution of different malaria or malaria-related parasite lineages. For example, a recent study has highlighted that malarial parasites in general can be the subject of different host-switching events and shifts in life-history traits, which in turn insures their maintenance within hosts further facilitated by a simplification of their life cycle [8].

Based on previous observations, bats are also hosts of different malaria-related parasites, including nine genera of Haemoproteidae [8-15], but only four of these, including the genus Polychromophilus, are diagnosed based on molecular tools, which calls for an in-depth investigation of haemosporidian parasites, including their epidemiology, host range, distribution, transmission, and patterns of speciation.

With respect to the genus Polychromophilus, which is limited to bats, five species have been formerly identified using morphological characters (Polychromophilus adami, Polychromophilus deanei, Polychromophilus corradetti, Polychromophilus melanipherus, and Polychromophilus murinus) of which two have been molecularly characterized ( $P$. melanipherus and P. murinus) infecting Miniopteridae $[16,17]$ and Vespertilionidae $[17,18]$, respectively. Further molecular research has revealed two additional taxa in Vespertilionidae hosts, classified as Polychromophilus species 1 in Kerivoula hardwickii from Cambodia [16] and Polychromophilus sp. 2 in Pipistrellus grandidieri (currently, Pipistrellus aff. grandidieri [19]) and Laephotis capensis from Guinea [10]. The remaining three species, Polychromophilus adami, P. deanei, and P. corradetti have only been diagnosed using morphological characters, and their taxonomic identity needs further molecular characterization.

On Madagascar, 46 species of bats are currently recognized with a level of endemism approaching $80 \%$ (Goodman et al. pers. commun.). Bat species diversity in the eastern mesic portions of the island is lower than in the western dry zone [20, 21]. In terms of microorganisms hosted by Malagasy bats, different published studies have demonstrated the circulation of viruses, bacteria, and metazoan parasites in these nocturnal mammals [22-25]. Besides parasites of potential medical importance, bats from Madagascar also host malaria-related parasites, namely the genus Polychromophilus (Haemosporida: Plasmodiidae). Two species of Polychromophilus are currently documented in Malagasy bats: P. melanipherus infecting Miniopterus spp. and rarely Paratriaenops furculus (Rhinonycteridae) and P. murinus parasitizing Myotis goudoti (Vespertilionidae) [17, 26]. While 32 species of bats occurring in the western and the central portion of Madagascar were already screened for the presence of Polychromophilus [16, 17, 26], knowledge on Polychromophilus in bats occurring in the eastern area is not well-known and aspects on biotic and abiotic drivers of infection are far from complete. In the present study, Polychromophilus diversity and distribution in bats living in the oriental portion of the island was explored and the potential drivers of Polychromophilus infection across the island predicted based on new and previous records.

\section{Methods \\ Study sites}

Fieldwork to sample bats was undertaken from 2014 to 2016 at four main sites in eastern Madagascar: Kianjavato Forest Station within the Paysage Harmonieux Protégé $\mathrm{du}$ Corridor Forestier Ambositra-Vondrozo and surrounding areas; Réserve Naturelle Intégrale de Betampona; Parc National de Masoala; and Parc National de Marojejy (Fig. 1, Additional file 1: Table S1). A range of habitat types were investigated, including day roosts in buildings, degraded areas associated with croplands, and lowland moist evergreen forests.

\section{Bat sampling}

Bats were captured using mist nets and harp traps erected across flight pathways. Additionally, a hand net was used to capture bats inside day roost sites. Upon capture, each individual bat was placed separately in a clean cloth bag. Bat voucher specimens were morphologically identified and deposited at the Université d'Antananarivo, Mention Zoologie et Biodiversité Animale (formerly Département de Biologie Animale, UADBA), Antananarivo, and in the Field Museum of Natural History (FMNH), Chicago. The recent revision of Monadjem et al. [19] was followed for the taxonomy of certain Afro-Malagasy members of the family Vespertilionidae. 


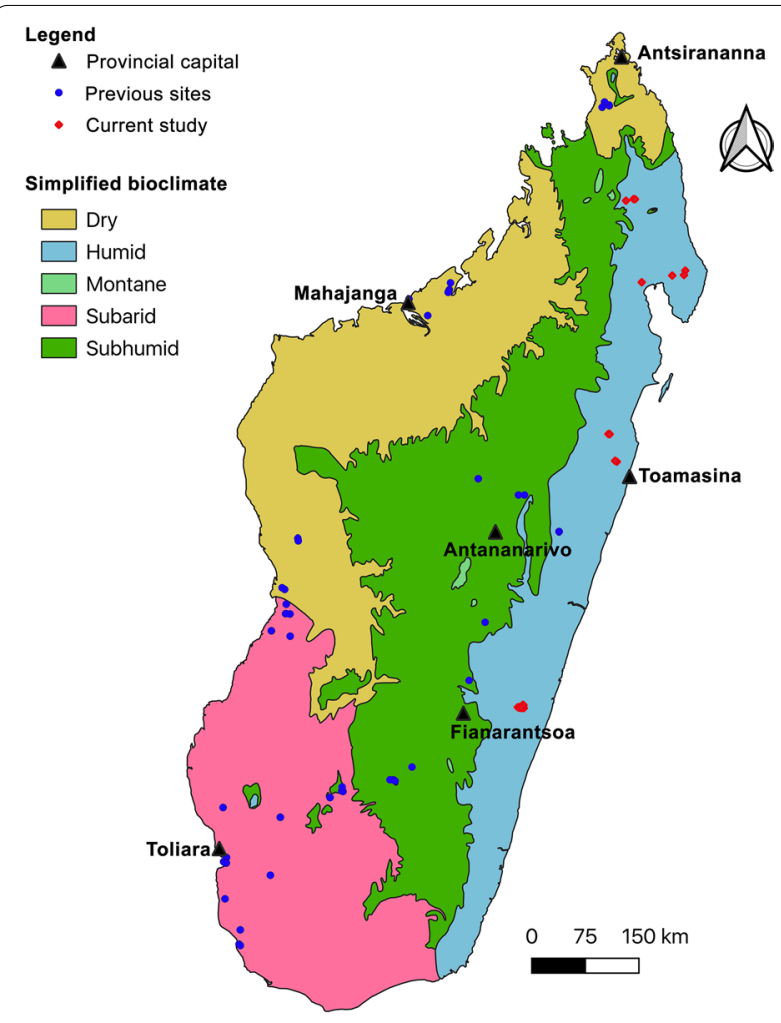

Fig. 1 Localization of the different sites included in the current and previous studies

\section{Blood smear screening and prevalence of the infection}

In the field, one thin blood smear per individual bat was prepared using a non-calibrated drop of blood. In the laboratory, blood smears were fixed with methanol, stained with Giemsa for $10 \mathrm{~min}$ at room temperature, rinsed with phosphate-buffered saline solution, and air-dried. Smears were subsequently examined using a Leica microscope (Leitz, Portugal) under 1000x magnification. For each blood smear, all monolayer fields were screened for the presence of haemosporidian parasites. The prevalence of the infection per species was obtained by dividing the number of infected individuals by the total number of individuals examined for each species [27, 28].

\section{DNA extraction, PCR amplification, and sequencing}

In the field, blood spots from each individual bat were conserved on Whatman filter paper, air-dried, and stored at room temperature until DNA extraction. In the laboratory, two blood spots from microscopically positive samples were lysed in $0.5 \%$ saponin solution during four hours at room temperature. Subsequently, they were washed with phosphate-buffered saline solution (PBS 1X). Total DNA extraction was performed using Instagene ${ }^{\mathrm{TM}}$ Matrix (BioRad, USA) following the manufacturer's protocol. PCR amplification targeting the portion of mitochondrial Cytochrome $b$ locus (Cyt $b$ ) of haemosporidian parasites was undertaken using a previously described nested PCR protocol[16, 18, 26] using Plas 1 and Plas 2 for the first PCR and Plas 3 and Plas 4 for the second PCR. PCR products were visualized in an electrophoresis gel and subsequently sent for Sanger sequencing to Genoscreen (Lille, France) using Plas 3 and Plas 4 primers.

\section{Phylogenetic analysis}

Nucleotide sequences obtained from positive individual bats were manually edited using Geneious software [29]. Individual nucleotide sequences were subsequently aligned with other data on bat blood parasites downloaded from Genbank using MAFFT alignment implemented in Geneious software. Prior to determining the phylogenetic relationship of the parasites sequenced, the best substitution model was identified using jModelTest version 2.1.3 [30, 31] revealing GTR $+\mathrm{I}+\mathrm{G}$ as the best substitution model. Subsequently, Bayesian inference consisting of two independent runs of four incremental Metropolis Coupled Markov Chain Monte Carlo (MC3) iterations starting from a random tree was conducted using MrBayes 3.1.2 [32]. This analysis consisted of two runs of 5,000,000 generations with trees and associated model parameters sampled every 500 generations. The first $25 \%$ of the trees were discarded as a burn-in. New nucleotide sequences produced in the present study were deposited to Genbank under Accession numbers MW039207 to MW039233 (Additional file 2: Table S2).

\section{Statistical analysis and Maxent modelling of Polychromophilus}

A Generalized Linear Model (GLM) was constructed to investigate variation in Polychromophilus infection between Miniopterus spp. and sex classes using R version 3.0.0 [33]. Results of the GLM are expressed as adjusted odd-ratio with confidence interval at $95 \%$. The identification of variables controlling the distribution of P. melanipherus was conducted using the MaxEnt software version 3.3.3k [34]. Modelling was carried out using occurrence records obtained in the present study, as well as another recent study [26]. Environmental variables for each of the capture sites [34, 35] included the following nine bioclimatic variables: annual total evapotranspiration, maximum precipitation of the wettest month, minimum precipitation of the driest month, maximum temperature of the warmest month, minimum temperature of the coldest month, mean annual precipitation, mean annual temperature, numbers of months with a positive water balance, and annual water balance. These data were recovered at 30 arc seconds resolution for each 
site at [36]. Elevational data was downloaded from; Geology from the simplified geological map of Madagascar [37] and vegetation cover taken from Rakotondratsimba [38].

Model accuracy was assessed by splitting occurrence data into $70 \%$ for training and $30 \%$ for testing [34]. This approach was repeated five times. A set of 10,000 random points was used as background data to generate the Area under the Curve (AUC) [39, 40]. Models with an AUC above 0.8 were considered as informative [39, 41]. The output of MaxEnt modelling is presented in map form showing the probability of suitable and unsuitable area [34].

\section{Results}

\section{Blood smear screening}

In total, 222 bats belonging to 17 species were microscopically screened for the presence of haemosporidian parasites. Thirty-six individual bats representing six species from two families were found positive. Four of the six screened species of Miniopterus (Miniopteridae), as well as Myotis goudoti and Scotophilus robustus (Vespertilionidae), were positive for haemosporidian infection (Table 1). This is the first report of haemosporidian parasites in S. robustus, a species endemic to Madagascar. The prevalence of the infection ranged from 20 to $54.5 \%$ in Miniopterus spp. $(\mathrm{n}=88), 8 \%$ in Myotis goudoti $(\mathrm{n}=25)$, and $33 \%$ in Scotophilus robustus $(\mathrm{n}=3)$ (Table 1). Based

Table 1 Polychromophilus infection in bats from eastern Madagascar based on blood smear screening

\begin{tabular}{llrl}
\hline Family & Species & N & Infected (in \%) \\
\hline Pteropodidae & Rousettus madagascariensis & 25 & 0 \\
Hipposideridae & Macronycteris commersoni & 1 & 0 \\
Emballonuridae & Coleura kibomalandy & 9 & 0 \\
& Paremballonura atrata & 27 & 0 \\
Myzopodidae & Myzopoda aurita & 17 & 0 \\
Molossidae & Chaerephon atsinanana & 12 & 0 \\
& Mopsleucostigma & 11 & 0 \\
Vespertilionidae & Myotis goudoti & 25 & $2(8)$ \\
& Laephotis matroka & 2 & 0 \\
& Pipistrellus raceyi & 2 & 0 \\
& Scotophilus robustus & 3 & $1(33)$ \\
Miniopteridae & Miniopterus ambohitrensis & 9 & $3(33)$ \\
& Miniopterus brachytragos & 6 & 0 \\
& Miniopterus cf. aelleni & 3 & 0 \\
& Miniopterus egeri & 5 & $1(20)$ \\
& Miniopterus gleni & 43 & $17(39.5)$ \\
& Miniopterus griveaudi & 22 & $12(54.5)$ \\
& Total & 222 & $36(16.2)$ \\
& & &
\end{tabular}

$N$ number of individuals analyzed on Generalized Linear Model analyses, the prevalence presented variation between species $(p=0.036)$ but not between sexes $(\mathrm{p}=0.44)$. For the different positive species of Miniopterus, two, Miniopterus gleni (Adjusted OddRatio: 2.17, CI 0.21-22.5) and Miniopterus griveaudi (Adjusted Odd-Ratio: 3.86, CI 0.35-43.05)—featured a high prevalence compared to the other species analysed.

\section{Phylogenetic analysis}

In total, 27 samples were amplified and sequenced. The Bayesian analysis based on 91 nucleotide sequences from Cyt $b$ gene from this study, as well as those from different areas around the world, showed that the genus Polychromophilus forms a well-supported monophyletic clade (Fig. 2). Within this cluster, five branches are observed: $P$. melanipherus in members of the family Miniopteridae, P. murinus in Vespertilionidae, Polychromophilus sp. 1 in Kerivoula hardwickii from Cambodia, Polychromophilus sp. 2 in two species of Vespertilionidae (Pipistrellus aff. grandidieri and Laephotis capensis) from Guinea and a novel branch of Polychromophilus, annotated Polychromophilus sp. from S. robustus (Vespertilionidae) from Madagascar and Scotophilus kuhlii from Thailand. Nucleotide sequences of Polychromophilus from these two Scotophilus species present about 90 to $98 \%$ of similarities (one nucleotide sequence from Scotophilus in Thailand (MT750308) was excluded in this comparison because of its reduced length). For Malagasy bats, nucleotide sequences obtained from those captured in the eastern portion of the island are composed of three different taxa: $P$. melanipherus, $P$. murinus, and the novel lineage of Polychromophilus (Fig. 2, Additional file 2: Table S2).

\section{Distribution of Polychromophilusspp. on Madagascar}

Of the seven bat families investigated from Malagasy samples in the current and previous studies, Polychromophilus spp. infect mainly two bat families, Miniopteridae and Vespertilionidae, with P. melanipherus found in members of the family Miniopteridae (10 species infected), $P$. murinus parasitizing a member of the family Vespertilionidae (Myotis goudoti), and Polychromophilus sp. found in another vespertilionid (Scotophilus robustus) sampled at Kianjavato (Fig. 3 a, b).

\section{Polychromophilus sp.}

Polychromophilus sp., the novel lineage, was identified in Scotophilus robustus based on morphological and molecular screening, but little can be said about its distributional range in Madagascar due to the single known occurrence. 


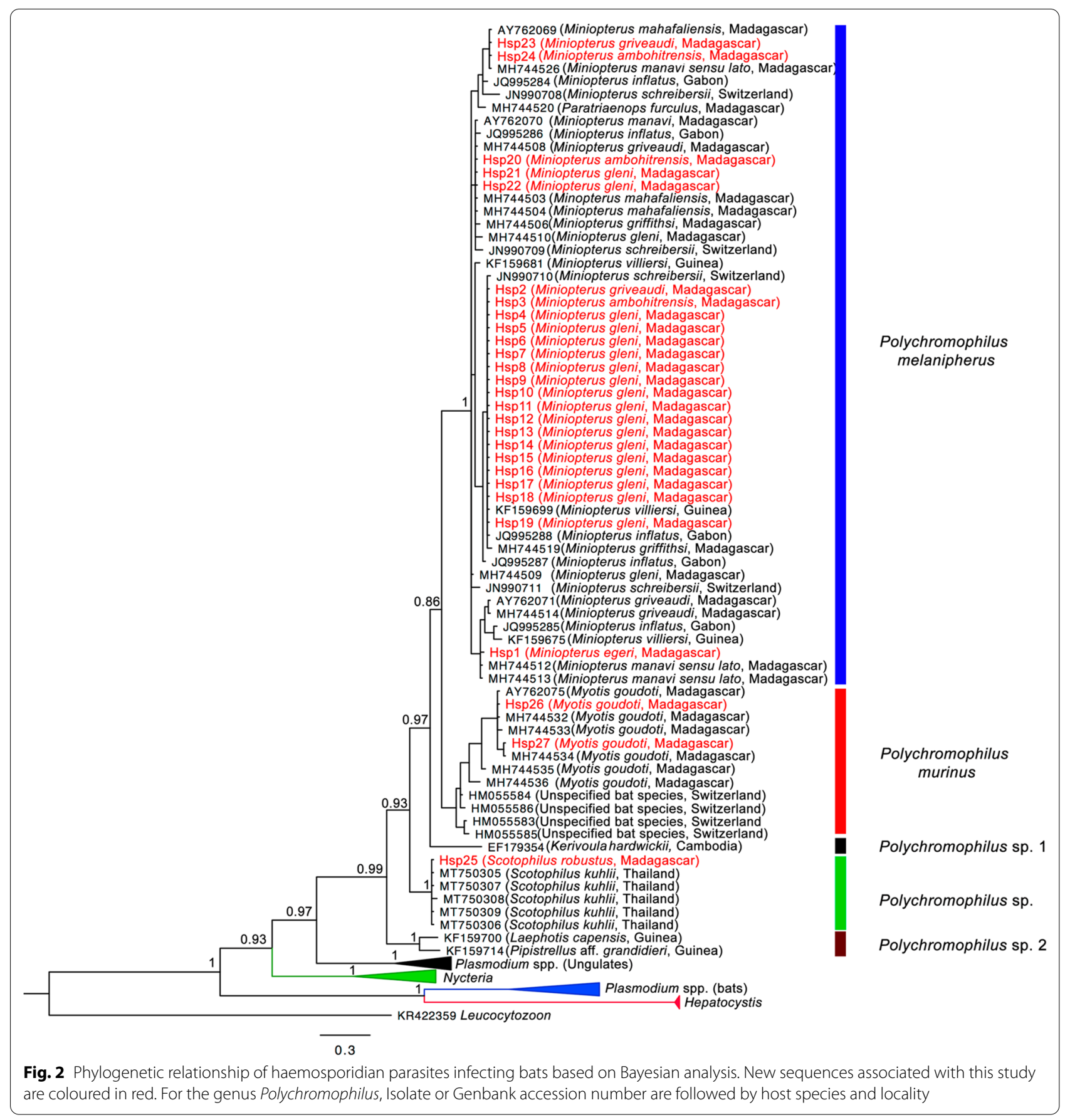

\section{Polychromophilus murinus}

Polychromophilus murinus was restricted to Myotis goudoti sampled at different sites across the island. Polychromophilus murinus was present in 11 out of the 17 sampled sites and based on current data is specific to Myotis goudoti (Additional file 3: Table S3)

\section{Polychromophilus melanipherus}

Polychromophilus melanipherus, associated with the genus Miniopterus, is a widespread parasite across the Old World distribution of the genus. Based on previous studies and data presented herein, $P$. melanipherus was identified from 23 out of the 28 sites sampled in 

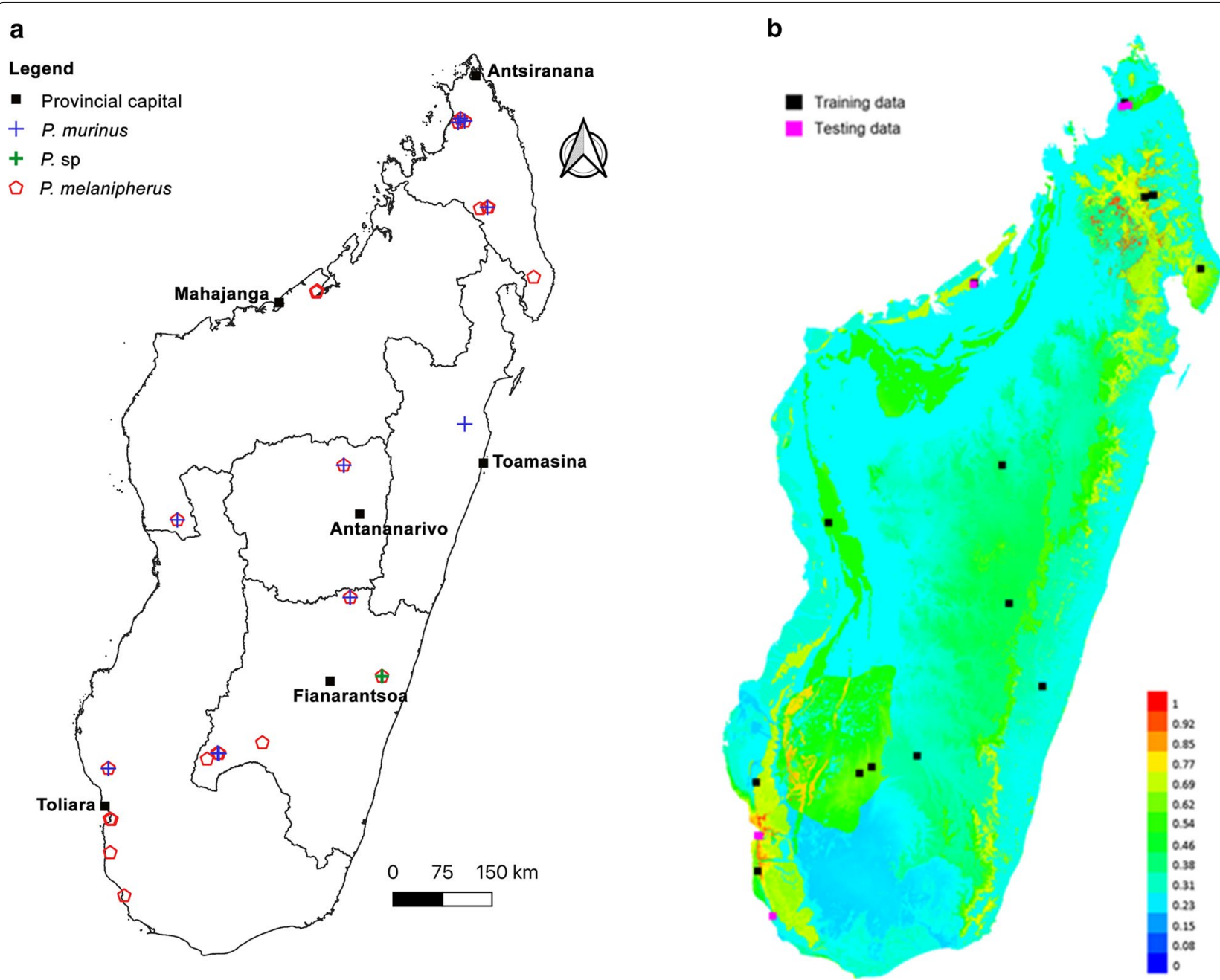

Fig. 3 a Distribution of Polychromophilus spp. on Madagascar. The different delineated areas represent provincial boundaries. b Predicted occurrence of Polychromophilus melanipherus on Madagascar based on MaxEnt analysis

Madagascar, including a range of different habitat types (Additional file 3: Table S3), this information was used in a MaxEnt analysis to model the parasites' presence on the island. The model had an AUC of 0.855 and the main four variables predicting suitable habitat on the presence of Polychromophilus were vegetation (61.1\%), geology (29.4\%), annual water balance $(4.9 \%)$, and annual total evapotranspiration $(4.6 \%)$. The remaining eight variables were less explicative (percent contribution between 0 and $1.3 \%)$ and were omitted from the final model.

MaxEnt prediction indicated an area of highest environmental suitability in the northern and southwestern areas of Madagascar, corresponding to orange to red colours (Fig. 3b), with a probability of infection ranging from 0.7 to 1 . Further, P. melanipherus may occur in diverse areas with different environmental conditions, corresponding to the green colourand a probability of infection ranging from 0.54 to 0.69 (Fig. 3b). Based on recent vegetation classification of Madagascar, regions of highest suitability for Polychromophilus included northern moist evergreen forest, southwestern dry spiny thicket, and western dry deciduous forest. It appears that in Madagascar $P$. melanipherus is tightly associated with the presence of Miniopterus spp.

\section{Discussion}

\section{Polychromophilus infection in Malagasy bats} and phylogenetic analyses

On the basis of the results presented herein including the analysis of seven different families of bats, Polychromophilus infection in Malagasy bats from the eastern portion of the island appears to be limited to two families (Miniopteridae and Vespertilionidae), while the other five tested families (Pteropodidae, Hipposideridae, Emballonuridae, Myzopodidae, and Molossidae) were negative. It is also known from Malagasy members of the family 
Rhinonycteridae (see below). Such host-parasite associations are congruent with previous investigations carried out in different portions of the world [10, 17, 18, 26, 42]. To date, 10 out of the 12 species of Miniopterus tested and occurring on Madagascar are infected by P. melanipherus based on morphological or molecular screenings. Miniopterus brachytragos was represented by six individuals in the current study, which were all negative. Hence, the absence of $P$. melanipherus infection in $M$. brachytragos may be associated with the limited sample size, as this species was previously found infected by Haemosporidae [43]. Miniopterus petersoni, with a limited geographical distribution [44], has not yet been analysed to date due to the absence of blood samples. Based on GLM analysis, $M$. gleni and $M$. griveaudi present higher risk of infection than the other Malagasy species within this genus. This may be due to their roosting behaviour, as these two species occur in large day roosting colonies within caves and both species have broad geographical distributions and little genetic variability, which can be related to their high dispersal capacity [44-46].

Phylogenetic analysis based on a portion of Cyt $b$ gene of Polychromophilus spp. in bats from different localities showed that they form a monophyletic group composed of five distinct clades, of which three are documented on Madagascar. Polychromophilus melanipherus was identified in Miniopterus spp., providing further support that this species of blood parasite being specific to the Miniopteridae, which has a broad Old World distribution [8, 10, 47]. This parasite infects different species of Miniopterus regardless of presumed geographic or host species barriers [10, 17, 42, 48]. Apart from Miniopterus spp., Paratriaenops furculus (Rhinonycteridae) has already been reported to be infected with Polychromophilus melanipherus [26], whereas a closely related member of this family, Triaenops menamena, which occurs in the same day roost sites as Paratriaenops furculus $[44,49]$ tested negative $(\mathrm{n}=42)$ for this parasite [26].

The second clade represented by Polychromophilus murinus, occurred in different genera and species of the family Vespertilionidae [26, 50, 51]. Compared to infection of P. murinus in European bats, based on current data from Malagasy Vespertilionidae, only Myotis goudoti is infected by P. murinus. A third lineage of Polychromophilus, identified herein as Polychromophilus sp. based on molecular data, was found in a single specimen of Scotophilus robustus (Vespertilionidae). The phylogenetic tree shows that this last lineage falls within the same cluster as sequences from S. kuhlii from Thailand [52] representing an undescribed Polychromophilus taxon. With one positive specimen among three captured individuals of $S$. robustus and five sequences from Scotophilus from Thailand, it would appear that this parasite may be strictly associated with the genus Scotophilus spp.; further samples and analyses are needed to resolve the taxonomy of Polychromophilus sp. based on morphological and molecular diagnosis.

The other two Polychromophilus clusters identified in Fig. 2 as Polychromophilus sp. 2 in Laephotis capensis and Pipistrellus aff. grandidieri from West Africa, and Polychromophilus sp. 1 in Kerivoula hardwickii from southeast Asia $[10,16]$ also need further investigation to have additional information on their taxonomy. To date, 38 out of the 46 species of bats occurring on Madagascar have been screened for the presence of apicomplexan parasites. The balance of eight species needs to be examined as material becomes available. Interestingly, Plasmodium from ungulates (as exemplified by P. bubalis and P. odocoilei) are closely related to Polychromophilus from bats.

\section{Distribution of Polychromophilus spp. in Madagascar}

Data on P. melanipherus was used to model the distribution of this bat blood parasite in members of the genus Miniopterus, as these bats are widespread on Madagascar from sea level to up to $1800 \mathrm{~m}$ [44]. Data from Raharimanga et al. [43] was not included in the modelling analysis presented herein as no molecular haematoparasite data was available for species determination. In total, 10 out of the 11 Miniopterus spp. screened for the presence of $P$. melanipherus were positive. Members of the family Miniopteridae use a range of roost sites such as caves, crevices or rock overhangs [44, 49] and generally live in mixed colonies with other species, often Myotis goudoti [44]. The dispersal capacity for certain members of the genus on Madagascar with broad geographic distributions is notably high, as exemplified by Miniopterus gleni and M. griveaudi [44, 49]. Polychromophilus melanipherus appears to be a cosmopolitan blood parasite of Miniopterus spp. across the Old World.

Based on the Maxent analysis, vegetation and geology are the two most significant parameters and contributed to more than $90 \%$ of the variables explaining the occurrence of $P$. melanipherus on Madagascar. The vegetation variable showed a notabledifference between the western and eastern portions of the island. In the west, three main vegetation types occur, including dry forest in the north, dry deciduous forest in the central area, and dry spiny thicket in the southwest. These vegetational gradients are important in the ecology of Miniopterus spp. associated with their feeding behaviour at a local scale and their dispersal at a broader geographical scale. In addition, throughout much of the west exposed limestone formations occur and often with extensive cave systems where Miniopterus spp. roost in sympatry or in syntopy within the cave. At such day roost sites, Miniopterus, as well as other bat species, most notably Myotis goudoti, occur in 
large to moderately large mono- or multi-specific groups, which may favour parasite exchange.

The analysis indicates that the eastern and central portions of Madagascar, characterized by natural moist evergreen forests and mesic climatic conditions, are less favourable for Miniopterus. Also, the local geology of this area lacks exposed sedimentary rock and deep cave formations; this results in bat day roost sites being limited to crevices or tree holes and smaller roosting groups. While P. melanipherus is associated with the genus Miniopterus, several abiotic variables help explain the lower prevalence of this parasite in the eastern portion of the island. It is important to mention that $P$. melanipherus and $P$. murinus generally co-occur within the same locality as their respective hosts sometimes live in sympatry or in syntopy within their day roost sites but no case of co-infection in a single individual is known.

\section{Drivers of Polychromophilus infection in bats}

Dick and Dittmar [53] hypothesized that the type of day roost site, colony size, and bioclimatic aspects can affect the exposure of bats to insect vectors, and, hence, parasite transmission. Based on the results obtained herein and data from the literature, on Madagascar Polychromophilus infection is limited to several species from three different families of bats, and some inferences based on the analyses presented herein can be presented about potential drivers of Polychromophilus infection. To this end, it is possible that Polychromophilus infection in bats is driven by two main factors: the ecological niche they occupy and the behavioural aspects of bat hosts and the presence of competent vectors.

\section{Ecological niche and bat behaviour}

The three Polychromophilus taxa identified in Malagasy bats show a certain level of host specificity that may be related to the ecological niche and behaviour of their bat hosts. As P. melanipherus infects almost all Miniopterus spp. on Madagascar, hypotheses regarding parasites maintenance and transmission can be suggested. The genus Miniopterus occurs in a wide range of habitats on the island with some of the species forming large monospecific or multispecific colonies. Miniopterus gleni and M. griveaudi often live in caves and rock shelters located near freshwater streams or in areas protected from solar radiation and with local humid conditions. Further, these two bat species often share or occur in relatively close proximity to other cave roosting bat species. Miniopterus gleni is the only species with a large distribution across much of the island, from sea level to $1200 \mathrm{~m}$, and can also co-occur with other members of the genus [49]. Further, phylogeographic studies show little genetic variation across the different localities it is known from and it can be presumed to disperse widely [45]. The role of this species as a bridge for Polychromophilus transmission is therefore probable. Nonetheless, this supposition needs further consideration with regards to the ecology, ectoparasites, and behaviour of this bat species.

Polychromophilus murinus on Madagascar is only known from Myotis goudoti. This endemic bat species shows little phylogeographical structure, best explained by broad dispersal [54]. Myotis goudoti occurs in various habitat types on the island and small to large day roosts are known from caves, crevices, and tree holes [44]. Although this species often occurs in syntopy in the same day roost site with small or middle-sized Miniopterus, such as M. griveaudi, M. ambohitrensis, or M. majori, no co-infection of $P$. murinus has been reported and best interpreted as the occurrence of distinct transmission filters between genera/families of bats.

\section{Presence of competent vectors and fly/bat specificity} Polychromophilus has been proposed to be transmitted by bat flies (Diptera: Hippoboscoidea: Nycteribiidae) [12], which are highly specialized ectoparasites [55-58]. Nycteribiid flies and their associated bat hosts show a strong association providing the means for parasite transmission through their respective life cycles. As a vector-borne infection, the transmission of Polychromophilus is presumably insured by the presence of competent vectors that are tightly associated with bat hosts. The molecular screening of 38 individual nycteribiids belonging to three species (Penicillidia leptothrinax, Penicillidia sp. cf. fulvida, and Nycteribia stylidiopsis) revealed the presence of Polychromophilus spp. [26]. While no detailed work on the role of Nycteribiidae as vector of Polychromophilus has been conducted on Madagascar, three species of Nycteribiidae, namely Penicillidia leptothrinax, Nycteribia stylidiopsis and Penicillidia sp. are local candidate vectors of Polychromophilus [26]. Penicillidia leptothrinax and $N$. stylidiopsis have been previously reported positive for Polychromophilus melanipherus. These positive bat flies included four Penicillidia leptothrinax specimens (two sampled on Miniopterus aelleni and two on M. manavi sensu lato), in addition to a single $N$. stylidiopsis obtained from M. gleni. These two bat fly species are common on bats of the genus Miniopterus and can be putatively considered as vectors of Polychromophilus melanipherus $[26,57]$. As far as P. murinus is concerned, one specimen of Penicillidia sp. was found positive and collected on a Miniopterus individual that was negative to Polychromophilus melanipherus, and this result probably indicates considerable ectoparasite exchange between members of the genera Miniopterus and Myotis, which is supported by three shared species 
of nycteribiids ( $N$. stylidiopsis, Penicillidia decipiens, and P. leptothrinax) (Dick, pers. commun.). Based on available information, it can be assumed that these three species of Nycteribiidae are candidate vectors of Polychromophilus spp. in Malagasy bats. Given the lack of host specificity in nycteribiid flies between Malagasy bats of the genera Miniopterus and Myotis and the proposed role of these ectoparasites in Polychromophilus infection, it might be assumed that there would be less host specificity in P. murinus and P. melanipherus. However, this is not the case and some other form of filter seems to be in place to reduce cross-genera infection. In contrast,Polychromophilus sp. is only known to date from Scotophilus robustus, which is the host for a different genus of nycteribid (Basilia) never collected on Malagasy Miniopterus or Myotis.

\section{Conclusions}

Across the Old World, Polychromophilus melanipherus infection is widespread in Miniopterus spp. (family Miniopteridae). Malagasy members of the family Vespertilionidae are infected by two different species of Polychromophilus. Based on current findings, three taxa of Polychromophilus are currently known in bat species from the island. While $P$. melanipherus and $P$. murinus appeared to be broadly distributed within their identified hosts namely Miniopterus spp. and Myotis goudoti, respectively, the third identified Polychromophilus taxon represents a new lineage. According to the data presented herein, Polychromophilus is closely related with specific hosts (species or families) and their occurrence is linked with the abiotic factors as exemplified by the MaxEnt analysis of P. melanipherus, as well as the presence of nycteribiid vectors favouring parasite transmission. Although the majority of Malagasy bat species have now been examined for the presence of Polychromophilus spp. using morphological and/or molecular screening, additional work is needed on the few non-analysed species and to increase sample sizes for some others that have not tested positive. Future studies should focus on the life cycle of Polychromophilus spp., and their evolutionary history and potential adverse effect on the bat hosts. Further, the importance of nycteribiid flies in the transmission of the different species of Polychromophilus in bats from Madagascar should be investigated.

\section{Supplementary Information}

The online version contains supplementary material available at https://doi. org/10.1186/s12936-021-03696-0.

Additional file 1: Table S1. Localities sampled in the previous and present study.
Additional file 2: Table S2. Genbank accession numbers of blood parasites included in the present study. Isolates and their Genbank accession number produced in the frame of the present work are highlighted in bold. FMNH Field Museum of Natural History, UADBA Université d'Antananarivo, Département de Biologie Animale.

Additional file 3: Table S3. Localities with positive occurrence of Polychromophilus in Madagascar including the origin of the sample (cave or trapping) and their location (latitude, longitude).

\section{Acknowledgements}

We are grateful to Madagascar National Parks and the Direction Générale des Forêts for authorizations and permits to conduct this research. We acknowledge local guides and village committees for their help with the fieldwork. We also thank the two anonymous reviewers for their comments and suggestions to improve the final version of this manuscript.

\section{Authors' contributions}

$M R, B R$, and SMG designed the study, MR and BR did the experiment, MR, BR and $M b R$ performed data analyses, MR, BR, MbR, SMG, PT, KD, and MiR wrote the manuscript. All authors read and approved the final manuscript.

\section{Funding}

This research was financially supported by Leona M. and Harry B. Helmsley Charitable Trust grant to Association Vahatra and Institut Pasteur de Madagascar.

Availability of data and materials

All data generated or analysed during this study are included in this article.

\section{Declarations}

\section{Ethics approval and consent to participate}

The study was conducted in strict accordance with the terms of research permits issued by Malagasy authorities (Direction du Système des Aires Protégées, Direction Générale de l'Environnement et des Forêts) and following national laws (Permit number no. 313/13/MEF/ SG/DGF/DCB.SAP/SCB of 30 December 2013; no. 103/16/MEEMF/ SG/DGF/DAPT/SCBT of 29 April 2016). Bats were captured, manipulated, and euthanized in accordance with guidelines accepted by these different national authorities and the scientific community for the handling of wild animals [59].

\section{Consent for publication \\ Not Applicable.}

\section{Competing interest}

The authors declare no competing interests.

\section{Author details}

${ }^{1}$ Institut Pasteur de Madagascar, Antananarivo 101, BP 1274, Ambatofotsikely, Madagascar. ${ }^{2}$ Faculté des Sciences, Université d'Antananarivo, BP 706, Antananarivo 101, Antananarivo, Madagascar. ${ }^{3}$ Association Vahatra, Antananarivo 101, BP 3972, Antananarivo, Madagascar. ${ }^{4}$ Field Museum of Natural History, 1400 South Lake Shore Drive, 60605 Chicago, IL, USA. ${ }^{5}$ Faculté des Sciences, Université de Toliara, 601 Toliara, Madagascar. ${ }^{6}$ Institut Pasteur (International Division), 25-28 Rue du Dr Roux, 75015 Paris, France. ${ }^{7}$ Université de La Réunion, UMR Processus Infectieux en Milieu Insulaire Tropical (PIMIT), INSERM 1187, CNRS 9192, IRD 249, 97490 Sainte-Clotilde, La Réunion, France.

Received: 19 October 2020 Accepted: 11 March 2021

Published online: 20 March 2021

References

1. Smith TG. The genus Hepatozoon (Apicomplexa: Adeleina). J Parasitol. 1996:82:565 - 85 .

2. Morrison DA. Evolution of the Apicomplexa: where are we now? Trends Parasitol. 2009;25:375-82. 
3. Perkins SL, Schaer J. A modern menagerie of mammalian malaria. Trends Parasitol. 2016;32:772-82.

4. Smith ML, Styczynski MP. Systems biology—based investigation of hostPlasmodium interactions. Trends Parasitol. 2018;34:617-32.

5. WHO. World Malaria Report. Geneva: World Health Organization; 2018

6. Perkins SL, Schall JJ. A molecular phylogeny of malarial parasites recovered from cytochrome $b$ gene sequences. J Parasitol. 2002;88:972-8.

7. Martinsen ES, Perkins SL, Schall JJ. A three-genome phylogeny of malaria parasites (Plasmodium and closely related genera): evolution of lifehistory traits and host switches. Mol Phylogenet Evol. 2008;47:261-73.

8. Galen SC, Borner J, Martinsen ES, Schaer J, Austin CC, West CJ, et al. The polyphyly of Plasmodium: comprehensive phylogenetic analyses of the malaria parasites (order Haemosporida) reveal widespread taxonomic conflict. R Soc Open Sci. 2018;5:171780.

9. Landau I, Chavatte JM, Karadjian G, Chabaud A, Beveridge I. The haemosporidian parasites of bats with description of Sprattiella alecto gen. nov., sp. nov. Parasite. 2012;19:137-46.

10. Schaer J, Perkins SL, Decherd J, Leendertze FH, Fahr J, Weber N, et al. High diversity of West African bat malaria parasites and a tight link with rodent Plasmodium taxa. Proc Natl Acad Sci USA. 2013;110:17415-9.

11. Schaer J, Reeder DM, Vodzak ME, Olival KJ, Weber N, Mayer F, et al. Nycteria parasites of Afrotropical insectivorous bats. Int J Parasitol. 2015;45:375-84.

12. Adam JP, Landau I. Developmental stages of Polychromophilus sp., a parasite of insectivorous bats from the Congo-Brazzaville, in the nycteribiid fly Penicillidia fulvida Bigot 1889. Trans R Soc Trop Med Hyg. 1973;67:5-6.

13. Adam JP. Transmission d'hémosporidies par des anophèles cavernicoles dans les grottes du Congo (Brazzaville). Bull World Health Organ. 1965;32:598-602.

14. Landau I, Rosin G, Miltgen F, Hugot J-P, Leger N, Beveridge I, et al. Sur le genre Polychromophilus (Haemoproteidae, parasite de Microchiroptères). Ann Parasitol Hum Comp. 1980;55:13-32.

15. Garnham PC, Lainson R, Shaw JJ. A contribution to the study of the haematozoon parasites of bats. A new mammalian haemoproteid, Polychromophilus deanei n. sp. Mem Inst Oswaldo Cruz. 1971;69:119-27.

16. Duval L, Robert V, Csorba G, Hassanin A, Randrianarivelojosia M, Walston J, et al. Multiple host-switching of Haemosporidia parasites in bats. Malar J. 2007;6:157.

17. Duval L, Mejean C, Maganga GD, Makanga BK, Mangama Koumba LB, Peirce MA, et al. The chiropteran haemosporidian Polychromophilus melanipherus: a worldwide species complex restricted to the family Miniopteridae. Infect Genet Evol. 2012;12:1558-66.

18. Megali A, Yannic G, Christe P. Disease in the dark: molecular characterization of Polychromophilus murinus in temperate zone bats revealed a worldwide distribution of this malaria-like disease. Mol Ecol. 2011;20:1039-48.

19. Monadjem A, Richards L, Decher J, Hutterer R, Mamba ML, Guyton J, et al. A phylogeny for African Pipistrellus species with the description of a new species from West Africa (Mammalia: Chiroptera). Zool J Linnean Soc. 2021;191:548-74.

20. Goodman SM, Ramasindrazana B, Maminirina CP, Schoeman MC, Appleton B. Morphological, bioacoustical, and genetic variation in Miniopterus bats from eastern Madagascar, with the description of a new species. Zootaxa. 2011;2880:1-19.

21. Cardiff SG, Jenkins KB. The bats of Madagascar: a conservation challenge. Lessons in Conservation. 2016;6:80-108.

22. Cassel-Beraud AM, Fontenille D, Rabetafika L. Etude bactérienne, virale et parasitaire d'une population de chauves-souris Chaerophon pumila à Anjiro, Madagascar. Arch Inst Pasteur Madagascar. 1989;56:233-9.

23. Ramasindrazana B, Dellagi K, Lagadec E, Randrianarivelojosia M, Goodman SM, Tortosa P. Diversity, host specialization, and geographic structure of filarial nematodes infecting Malagasy bats. PLoS One. 2016;11:e0145709.

24. Dietrich M, Wilkinson DA, Soarimalala V, Goodman SM, Dellagi K, Tortosa P. Diversification of an emerging pathogen in a biodiversity hotspot: Leptospira in endemic small mammals of Madagascar. Mol Ecol. 2014;23:2783-96.

25. Lebarbenchon C, Ramasindrazana B, Joffrin L, Bos S, Lagadec E, Le Minter G, et al. Astrovirus in bats, Madagascar. Emerg Microbes Infect. 2017;6:e58.

26. Ramasindrazana B, Goodman SM, Dsouli N, Gomard Y, Lagadec E, Randrianarivelojosia M, et al. Polychromophilus spp. (Haemosporida) in
Malagasy bats: host specificity and insights on invertebrate vectors. Malar J. 2018;17:318.

27. Margolis L, Esch GW, Holmes JC, Kuris AM, Schad GA. The use of ecological terms in parasitology (Report of an ad hoc committee of the American Society of Parasitologists). J Parasitol. 1982;68:131-3.

28. Rabetafika L, Fontenille D, Albignac R, Rakotofiringa S, Coulanges P. Contribution à l'étude du paludisme des Lémuriens. Arch Inst Pasteur Madagascar. 1985;52:85-100.

29. Kearse M, Moir R, Wilson A, Stones-Havas S, Cheung M, Sturrock S, et al. Geneious Basic: an integrated and extendable desktop software platform for the organization and analysis of sequence data. Bioinformatics. 2012;28:1647-9.

30. Posada D. jModelTest: phylogenetic model averaging. Mol Biol Evol. 2008:25:1253-6.

31. Darriba D, Taboada GL, Doallo R, Posada D. jModelTest 2: more models, new heuristics and parallel computing. Nat Methods. 2012;9:772.

32. Ronquist F, Teslenko M, Van Der Mark P, Ayres DL, Darling A, Höhna S, et al. MrBayes 3.2: efficient Bayesian phylogenetic inference and model choice across a large model space. Syst Biol. 2012;61:539-42.

33. R: A language and environment for statistical computing. R Foundation for statistical computing. http://www.R-project.org/.

34. Philips SJ, Anderson RP, Schapire RE. Maximum entropy modeling of species geographic distributions. Ecol Modell. 2006;190:231-59.

35. Elith J, Phillips S, Hastie T, Dudik M, Chee Y, Yates C. A statistical explanation of MaxEnt for ecologists. Divers Distrib. 2011;17:43-57.

36. Hijmans RJ, Cameron SE, Parra JL, Jones PG, Jarvis A. Very high resolution interpolated climate surfaces for global land areas. Int J Climatol. 2005;25:1965-78.

37. Du Puy DJ, Moat J. A refined classification of the primary vegetation of Madagascar based on the underlying geology: Using GIS to maps its distribution and to assess its conservation status. In: Lourenço WR, Ed. Biogéographie de Madagascar. Paris: Editions ORSTOM; 1996:205-18.

38. Rakotondratsimba HM. Technical aspects associated with the realization of this atlas. In: Goodman SM, Raherilalao MJ, editors. Atlas of selected land vertebrates of Madagascar. Antananarivo: Association Vahatra; 2013. pp. 19-34.

39. Pearce J, Ferrier S. Evaluating the predictive performance of habitat models developed using logistic regression. Ecol Modell. 2000;133:225-45.

40. Barbet-Massin M, Jiguet F, Albert CH, Thuiller W. Selecting pseudoabsences for species distribution models: how, where and how many? Methods Ecol Evol. 2012;3:327-38.

41. Swets JA. Measuring the accuracy of diagnostic systems. Science. 1988;240:1285-93.

42. Lutz HL, Patterson BD, Kerbis Peterhans JC, Stanley WT, Webala PW, Gnoske TP, et al. Diverse sampling of East African haemosporidians reveals chiropteran origin of malaria parasites in primates and rodents. Mol Phylogenet Evol. 2016;99:7-15.

43. Raharimanga V, Ariey F, Cardiff SG, Goodman SM, Tall A, Rousset D, et al. Hémoparasites des chauves-souris à Madagascar. Arch Inst Pasteur Madagascar. 2003;69:70-6.

44. Goodman SM, Ramasindrazana B. Bats or the order Chiroptera. In: Goodman SM, Raherilalao MJ, editors. Atlas of selected land vertebrates of Madagascar. Antananarivo: Association Vahatra; 2013. pp. 169-209.

45. Goodman SM, Maminirina CP, Bradman HM, Christidis L, Appleton BR. Patterns of morphological and genetic variation in the endemic Malagasy bat Miniopterus gleni (Chiroptera: Miniopteridae), with the description of a new species, M. griffithsi. J Zool Syst Evol Res. 2010;48:75-86.

46. Goodman SM, Maminirina CP, Weyeneth N, Bradman HM, Christidis L, Ruedi $\mathrm{M}$, et al. The use of molecular and morphological characters to resolve the taxonomic identity of cryptic species: the case of Miniopterus manavi (Chiroptera, Miniopteridae). Zool Scripta. 2009;38:339-63.

47. Garnham PC. The zoogeography of Polychromophilus and description of a new species of a gregarine (Lankesteria galliardi). Ann Parasitol Hum Comp. 1973:48:231-42.

48. Witsenburg F, Salamin N, Christe P. The evolutionary host switches of Polychromophilus: a multi-gene phylogeny of the bat malaria genus suggests a second invasion of mammals by a haemosporidian parasite. Malar J. 2012;11:53.

49. Goodman SM. Les chauves-souris de Madagascar. Antananarivo: Association Vahatra; 2011. 
50. Witsenburg F, Schneider F, Christe P. Epidemiological traits of the malarialike parasite Polychromophilus murinus in the Daubenton's bat Myotis daubentonii. Parasit Vectors. 2014;7:556.

51. Gardner RA, Molyneux DH. Polychromophilus murinus: a malarial parasite of bats: life-history and ultrastructural studies. Parasitology. 1988;96:591-605.

52. Chumnandee C, Pha-obnga N, Werb O, Matuschewski K, Schaer J. Molecular characterization of Polychromophilus parasites of Scotophilus kuhlii bats in Thailand. Parasitology. 2020:1-5.doi:10.1017/S003118202000222X. (online ahead of print).

53. Dick CW, Dittmar K. Parasitic bat flies (Diptera: Streblidae and Nycteribiidae): host specificity and potential as vectors. In: Klimpel S, Mehlhorn $H$. Eds. Bats (Chiroptera) as vectors of diseases and parasites: Facts and myths. Berlin: Springer-Verlag; 2014. pp. 131-56.

54. Weyeneth N, Goodman SM, Ruedi M. Do diversification models of Madagascar's biota explain the population structure of the endemic bat Myotis goudoti (Chiroptera: Vespertilionidae)? J Biogeogr. 2011;38:44-54.

55. Dick CW, Patterson BD. Bat flies_obligate ectoparasites of bats. In: Morand S, Krasnov B, Poulin R R, editors. Micromammals and macroparasites: from evolutionary ecology to management. Japan: Springer-Verlag; 2006. pp. 179-94
56. Ramasindrazana B, Goodman SM, Gomard Y, Dick CW, Tortosa P. Hidden diversity of Nycteribiidae (Diptera) bat flies from the Malagasy Region and insights on host parasite interactions. Parasit Vectors. 2017;10:630

57. Tortosa P, Dsouli N, Gomard Y, Ramasindrazana B, Dick CW, Goodman SM. Evolutionary history of Indian Ocean nycteribiid bat flies mirroring the ecology of their hosts. PLoS One. 2013;8:e75215.

58. Obame-Nkoghe Jl, Rahola N, Bourgarel M, Yangari P, Prugnolle F, Maganga GD, et al. Bat flies (Diptera: Nycteribiidae and Streblidae) infesting cave-dwelling bats in Gabon: diversity, dynamics and potential role in Polychromophilus melanipherus transmission. Parasit Vectors. 2016;9:333.

59. Sikes RS, Gannon WL, The Animal Care and Use Committee of the American Society of Mammalogists. Guidelines of the American Society of Mammalogists for the use of wild mammals in research. J Mammal. 2011:92:235-53.

\section{Publisher's note}

Springer Nature remains neutral with regard to jurisdictional claims in published maps and institutional affiliations.
Ready to submit your research? Choose BMC and benefit from:

- fast, convenient online submission

- thorough peer review by experienced researchers in your field

- rapid publication on acceptance

- support for research data, including large and complex data types

- gold Open Access which fosters wider collaboration and increased citations

- maximum visibility for your research: over $100 \mathrm{M}$ website views per year

At BMC, research is always in progress.

Learn more biomedcentral.com/submissions 